Takafumi Watanabe • Issei Imoto • Yoshinori Kosugi

Yoji Fukuda · Junsei Mimura • Yoshiaki Fujii

Keiichi Isaka • Masaomi Takayama • Akira Sato

Johji Inazawa

\title{
Human arylhydrocarbon receptor repressor (AHRR) gene: genomic structure and analysis of polymorphism in endometriosis
}

Received: January 24, 2001 / Accepted: March 1, 2001

\begin{abstract}
The diversity of biological effects resulting from exposure to dioxin may reflect the ability of this environmental pollutant to alter gene expression by binding to the arylhydrocarbon receptor $(A H R)$ gene and related genes. $A H R$ function may be regulated by structural variations in $A H R$ itself, in the $A H R$ repressor $(A H R R)$, in the $A H R$ nuclear translocator $(A R N T)$, or in $A H R$ target molecules such as cytochrome P-4501A1 (CYP1A1) and glutathione $\mathrm{S}$-transferase. Analysis of the genomic organization of AHRR revealed an open reading frame consisting of a 2094bp mRNA encoded by ten exons. We found one novel polymorphism, a substitution of Ala by Pro at codon 185 (GCC to CCC), in exon 5 of the AHRR gene; among 108 healthy unrelated Japanese women, genotypes Ala/Ala, Ala/Pro, and Pro/Pro were represented, respectively, by 20 (18.5\%), $49(45.4 \%)$, and $39(36.1 \%)$ individuals. We did not detect previously published polymorphisms of $A R N T$ (D511N) or the CYP1A1 promoter (G-469A and C-459T) in our subjects, suggesting that these polymorphisms are rare in the Japanese population. No association was found between uterine endometriosis and any polymorphisms in the $A H R R, A H R, A R N T$, or CYP1A1 genes analyzed in the present study.
\end{abstract}

Key words $A H R R \cdot A H R \cdot \mathrm{SNPs} \cdot$ Endometriosis $\cdot$ Dioxin

T. Watanabe $\cdot$ I. Imoto $\cdot$ Y. Kosugi $\cdot$ Y. Fukuda $\cdot$ J. Inazawa $(\triangle)$ Department of Molecular Cytogenetics, Medical Research Institute, Tokyo Medical and Dental University, 1-5-45 Yushima, Bunkyo-ku, Tokyo 113-8519, Japan

Tel. +81-3-5803-5820; Fax +81-3-5803-5820

e-mail: johinaz.cgen@mri.tmd.ac.jp

T. Watanabe $\cdot$ A. Sato

Department of Obstetrics and Gynecology, Fukushima Medical

University, Fukushima, Japan

Y. Kosugi $\cdot$ K. Isaka $\cdot$ M. Takayama

Department of Obstetrics and Gynecology, Tokyo Medical

University, Tokyo, Japan

J. Mimura $\cdot$ Y. Fujii

Department of Chemistry, Graduate School of Science, Tohoku

University, Sendai, Japan

\section{Introduction}

Dioxin $(2,3,7,8$,tetrachlorodibenzo- $p$-dioxin) is one of the most toxic congeners among environmental pollutants. The toxicological effects of dioxin include acute inflammatory response, immune suppression, developmental and reproductive toxicity, and carcinogenesis (Poland and Knutson, 1982). The diversity of biological effects resulting from exposure to dioxin is thought to reflect its ability to alter gene expression through binding to the arylhydrocarbon receptor (AHR; Hoffman et al. 1991; Ema et al. 1992). Dioxin and other arylhydrocarbons bind to the PAS (Per-Arnt-Sim homology) domain of AHR, causing this protein to translocate from the cytoplasm to the nucleus, where it dimerizes with aryl hydrocarbon receptor nuclear translocator (ARNT; Reyes et al. 1992; Matsushita et al. 1993; Whitelaw et al. 1993). The AHR-ARNT heterodimer then transactivates target genes that encode enzymes involved in metabolizing arylhydrocarbons, such as cytochrome P-4501A1 (CYP1A1), glutathione S-transferase (GST), and others, by binding to xenobiotic response element (XRE) enhancer sequences in their regulatory regions (Fujisawa-Sehara et al. 1987; Telakowski-Hopkins et al. 1988).

Mimura et al. (1999) isolated a full-length cDNA for the murine arylhydrocarbon receptor repressor gene (Ahrr), whose sequence is similar to that of murine $A h r$ in the bHLH-PAS domain. In mice, Ahrr inhibits Ahr function by competing with Ahr for dimerizing with Arnt and binding to the XRE. The expression of Ahrr is induced by the AhrArnt heterodimer when the latter binds to the XRE of Ahrr; that is, Ahrr regulates Ahr function by negative feedback, and affects the expression of target genes that are induced by dioxin (Mimura et al. 1999).

In recent years, an increasing incidence of endometriosis has highlighted environmental factors as likely stimulants for the growth and maintenance of endometriosis lesions. Among these factors, dioxin is a prominent candidate for involvement in this disease, on the basis of experimental (Rier et al. 1993) and etiologic evidence (Bois and Eskenazi 1994; Mayani et al. 1997; Eskenazi et al. 2000). 
Recently, we isolated a full-length cDNA for the human arylhydrocarbon receptor repressor gene $(A H R R)$ and localized it to chromosome 5p (Y. Fujii, unpublished data). In the present study, we first determined its genomic structure and discovered a single-nucleotide polymorphism (SNP) of this gene in the Japanese population. Next, in order to determine whether an association might exist between endometriosis and this SNP or similar polymorphisms in $A H R, A R N T$, and/or the CYP1A1 promoter, we genotyped 45 Japanese women with sporadic endometriosis and a control group consisting of 84 healthy female volunteers and 24 women who had presented with a normal pelvis at laparoscopic observation or laparotomy.

\section{Subjects, materials, and methods}

\section{Identification of exon-intron boundaries of $A H R R$}

Bacterial artificial chromosome (BAC) clones containing the human AHRR gene were screened from the RPCI-11 library by the polymerase chain reaction (PCR), using two gene-specific primer pairs recommended by the manufacturer: for B138H19, 5'-TGACCACCATCCAAGCTCAG$3^{\prime}$ and $5^{\prime}$-ATGCTGTCATGCTTGAATAGAC- $3^{\prime}$ ); for B300J8, H1 and H2 (see Table 1) (Ikegawa et al. 1999). The exon-intron boundaries of $A H R R$ were determined with an ABI 377 sequencer (Applied Biosystems, Tokyo, Japan) by means of bi-directional sequencing of BAC clones with primers designed along the cDNA sequence, and comparison of genomic and cDNA sequences (Futamura et al. 1999). A contig was assembled by means of the Autoassembler program (Applied Biosystems).
Subjects and extraction of genomic DNAs

Genomic DNAs were prepared, as described by Pimkhaokham et al. (2000), from peripheral white blood cells of 45 women with moderate-to-severe endometriosis (stage III-IV; revised American Fertility Society), who had been diagnosed by laparoscopy or laparotomy at the Tokyo Medical University Hospital. Control DNAs were obtained from a total of 108 unrelated women (84 healthy volunteers and 24 women without endometriosis who were diagnosed with a normal pelvis during laparoscopic or laparotomic treatment for benign ovarian tumors at Tokyo Medical University). All of the women participating in the study were ethnically Japanese, and all provided their informed consent.

SNPs within $A H R, A R N T, A H R R$, and the $C Y P 1 A 1$ promoter

On the basis of flanking intronic sequences in the $A H R R$ gene, we designed oligonucleotide primers to amplify each exon (Table 1). All reactions were performed in volumes of $20 \mu \mathrm{l}$, containing 10ng genomic DNA, 1X PCR buffer, $0.25 \mu \mathrm{M}$ each primer, and EX-Taq DNA polymerase (Takara, Tokyo, Japan). Cycling conditions were: 35 cycles of $94^{\circ} \mathrm{C}$ for $30 \mathrm{~s}, 60^{\circ} \mathrm{C}-64^{\circ} \mathrm{C}$ for $30 \mathrm{~s}$, and $72^{\circ} \mathrm{C}$ for $30 \mathrm{~s}$. The specific annealing temperatures for each amplicon are listed in Table 1 . To amplify each known polymorphic site of $A R N T, A H R R$, and the CYP1A1 promoter, primer pairs and PCR conditions were employed as described by Kawajiri et al. (1995), Cao and Hegele (2000), and Smart and Daly (2000). PCR products were purified using QIAquick PCR Purification Kits (Qiagen, Tokyo, Japan),

Table 1. Primers used for sequence analysis of $A H R R$ gene

\begin{tabular}{|c|c|c|c|c|c|}
\hline \multicolumn{3}{|c|}{ Amplified DNA fragment } & \multicolumn{3}{|l|}{ Primer } \\
\hline Exon & Name & $\begin{array}{l}\text { Length } \\
\text { (bp) }\end{array}$ & Name & Sequence & $\begin{array}{l}\text { Annealing } \\
\text { temperature }\left({ }^{\circ} \mathrm{C}\right)\end{array}$ \\
\hline \multirow[t]{2}{*}{1} & \multirow[t]{2}{*}{ A } & \multirow[t]{2}{*}{133} & A1 & TGT CTT CCA GGC CGA GGA C & \multirow[t]{2}{*}{60} \\
\hline & & & A2 & CCC CTT CCA TGG GTG CAA C & \\
\hline \multirow[t]{2}{*}{2} & \multirow[t]{2}{*}{ B } & \multirow[t]{2}{*}{253} & B1 & CAC CTG ACC CAG ACC ATC TC & \multirow[t]{2}{*}{64} \\
\hline & & & B2 & CAG CCT GAC TCA AGT GAA CAG & \\
\hline \multirow[t]{2}{*}{3} & \multirow[t]{2}{*}{$\mathrm{C}$} & \multirow[t]{2}{*}{224} & $\mathrm{C} 1$ & GGT GCC TAA TGT GTC TTT TC & \multirow[t]{2}{*}{64} \\
\hline & & & $\mathrm{C} 2$ & CGT GAC ACG GAG TAT GAC TG & \\
\hline \multirow[t]{2}{*}{4} & \multirow[t]{2}{*}{$\mathrm{D}$} & \multirow[t]{2}{*}{198} & D1 & TTA AGC AAA GGA TTC TTG CAC & \multirow[t]{2}{*}{60} \\
\hline & & & D2 & CAG ACT GGA GGG CTA TTC TG & \\
\hline \multirow[t]{2}{*}{5} & \multirow[t]{2}{*}{$\mathrm{E}$} & \multirow[t]{2}{*}{245} & $\mathrm{E} 1$ & CTC GTC GGT GGA ATA AAG TG & \multirow[t]{2}{*}{64} \\
\hline & & & E2 & ACC TGC TTT AGG TTT TGC TG & \\
\hline \multirow[t]{2}{*}{6} & \multirow[t]{2}{*}{$\mathrm{F}$} & \multirow[t]{2}{*}{344} & $\mathrm{~F} 1$ & TGA CAT CTA GAG GGA TGC TG & \multirow[t]{2}{*}{62} \\
\hline & & & $\mathrm{F} 2$ & GGT AGA ATG CAT CCC AGA TG & \\
\hline \multirow[t]{2}{*}{7} & \multirow[t]{2}{*}{ G } & \multirow[t]{2}{*}{282} & G1 & TAA AAC ACC AGA CGA TGC AG & \multirow[t]{2}{*}{60} \\
\hline & & & G2 & GAG TGT GGA GGT GTT TTG TG & \\
\hline \multirow[t]{2}{*}{8} & \multirow[t]{2}{*}{$\mathrm{H}$} & \multirow[t]{2}{*}{203} & H1 & GTT CAT CCG TCA CAT GTC AC & \multirow[t]{2}{*}{60} \\
\hline & & & $\mathrm{H} 2$ & GAA TAC GCC AAC ATC TCC AC & \\
\hline 9 & I & 246 & I1 & TCT TCC AGG AGC TCC TCA G & 62 \\
\hline & & & $\mathrm{I} 2$ & ACG GTG ACT TAG GGA GCT G & \\
\hline $10-1$ & $\mathrm{~J}$ & 730 & $\mathrm{~J} 1$ & TTC GTA GCC TCC CTT TAG AG & 60 \\
\hline & & & $\mathrm{J} 2$ & GAT GTA CAC CTG TTG CCG AG & \\
\hline $10-2$ & $\mathrm{~K}$ & 611 & K1 & CCA TCA AGA TGG AGA AGG AC & 60 \\
\hline & & & $\mathrm{K} 2$ & CAA AGC GTG TGT CTT AGG AC & \\
\hline
\end{tabular}


and then directly sequenced with the 377 ABI sequencer (Applied Biosystems), using primers recommended by the manufacturer (Sugimoto et al. 1999).

\section{Statistical analysis}

We analyzed differences in frequencies of genotypes for $A H R$ and $A H R R$, as well as differences in allelic frequencies of each known SNP in $A H R, A H R R, A R N T$ and the $C Y P 1 A 1$ promoter, between patients with endometriosis and controls. A $P$ level of less than 0.05 was considered statistically significant.

\section{Results}

Genomic structure of $A H R R$

Two overlapping BAC clones (B138H19 and B300J8) were found to contain the full-length cDNA for $A H R R$, and we determined the genomic structure of this gene using these two BACs. The size of each exon and the sequence of each exon-intron boundary are presented in Table 2. All bound- aries were consistent with the invariable intronic AG and GT features that flank the beginning and end, respectively, of the majority of vertebrate exons. The open reading frame of $A H R R$ consists of a 2094-bp mRNA encoded by ten exons. The genomic structure (Fig. 1) is similar to that of the $A H R$ gene, except for the carboxy-terminal half, which includes the transactivation domain (Dolwick et al. 1993).

\section{Polymorphism in $A H R R$}

To discover SNPs within the coding region of $A H R R$, we sequenced all ten coding exons, using DNAs from 48 unrelated Japanese individuals. The coding sequence was divided into 11 parts (Table 1), and primers for amplifying each segment were designed on the basis of genomic sequence. We found one polymorphic site in exon 5 , a onebase substitution of alanine (Ala) for proline (Pro) at codon 185 (GCC to CCC). We then determined the frequency of the three genotypes of $A H R R$ at this site in 108 random controls. Genotypes Ala/Ala, Ala/Pro, and Pro/Pro were found in $20(18.5 \%), 49(45.4 \%)$, and 39 (36.1\%) individuals, respectively (Table $3 \mathrm{~A})$. This pattern of allelic frequency in women was similar to that in men determined in our preliminary study.
Fig. 1. Genomic organization of the AHRR gene. B300J8 and B138H19 indicate the two bacterial artificial chromosome (BAC) clones screened by polymerase chain reaction (PCR), using suitable sets of primers. The bHLH region (hatched area) belongs to exon 2, whereas the PAS domain (gray area) exists between exon 3 and exon 7 (Y. Fujii, unpublished data). The polymorphic site in exon 5 is indicated by an arrowhead

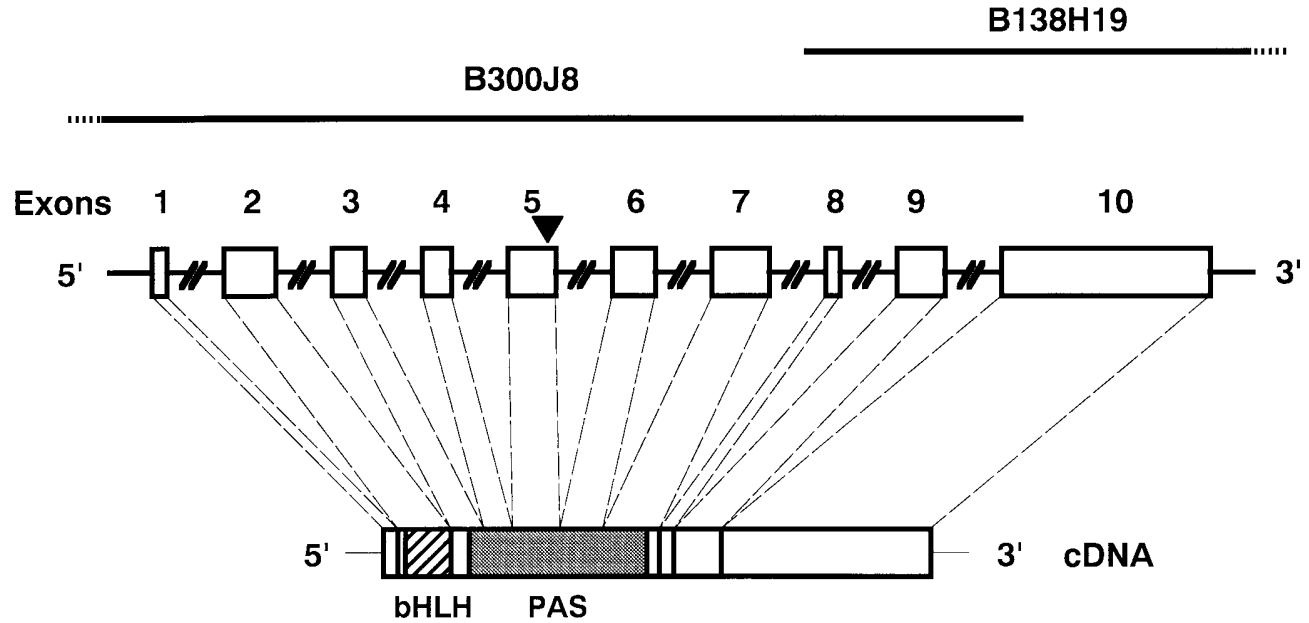

Table 2. Exon-intron boundary sequences of the $A H R R$ coding region

\begin{tabular}{|c|c|c|c|c|}
\hline $\begin{array}{l}\text { Exon } \\
\text { number }\end{array}$ & $\begin{array}{l}\text { Exon length } \\
\text { (bp) }\end{array}$ & $\begin{array}{l}\text { cDNA } \\
\text { position }\end{array}$ & Splice acceptor ${ }^{\mathrm{a}}$ & Splice donor $^{\mathrm{a}}$ \\
\hline 1 & 62 & $1-62$ & & TGCAGAAACA gtaaagtatc \\
\hline 2 & 182 & 63-244 & ctccccacag GAGGCCCGCC & TТСТТССАAG gtaggactct \\
\hline 3 & 107 & $245-351$ & tatctgacag TCGTGCAGGA & GCTGTTGGAG gtgagtactt \\
\hline 4 & 90 & $352-441$ & tttcttctag TCTCTTAATG & CTTCCATCAG gtaaatgaaa \\
\hline 5 & 130 & $442-571$ & gctatttcag TCAGACGGAT & TTGGAGACAG gtgggtgtct \\
\hline 6 & 137 & $572-708$ & tggtctgcag GAGATGATGC & GGGCTTCTCT gtgagtgcgt \\
\hline 7 & 201 & 709-909 & aaaacaccag ACGATGCAGT & CGGATGCAAA gtgagtaaga \\
\hline 8 & 61 & $910-970$ & ttcttcacag AGTAAAAGCC & TACTCAGCAG gtacttagaa \\
\hline 9 & 143 & 971-1113 & accccaacag GAAGGAGCAG & GGGGCTCAGG gtaagtggtg \\
\hline 10 & 981 & 1114-2094 & ttctctgcag GGACAGGGAG & \\
\hline
\end{tabular}

${ }^{a}$ Exon sequences are in capital letters, and intron sequences are in lowercase letters

The consensus sequences of the exon-intron junctions are indicated by underlines 
Table 3A,B. Genotypic and allelic frequencies at the $A H R R(\mathbf{A})$ and $A H R(\mathbf{B})$ polymorphisms

(A)

\begin{tabular}{|c|c|c|c|c|c|}
\hline & \multicolumn{3}{|c|}{$A H R R$ genotypes } & \multicolumn{2}{|c|}{$A H R R$ alleles } \\
\hline & Ala/Ala (\%) & Ala/Pro (\%) & Pro/Pro (\%) & Ala (\%) & Pro $(\%)$ \\
\hline Control $^{\mathrm{a}}$ & $20(18.5)$ & $49(45.4)$ & $39(36.1)$ & $89(41.2)$ & $127(58.8)$ \\
\hline Healthy volunteer ${ }^{\mathrm{b}}$ & $13(15.5)$ & $43(51.2)$ & $28(33.3)$ & 69 (41.1) & $99(58.9)$ \\
\hline Nonendometriosis ${ }^{\mathrm{c}}$ & $7(29.2)$ & $6(25.0)$ & $11(45.8)$ & $20(41.7)$ & $28(58.3)$ \\
\hline \multirow[t]{2}{*}{ Endometriosis $^{\mathrm{d}}$} & $5(11.1)$ & $20(44.4)$ & $20(44.4)$ & $30(33.3)$ & $60(66.7)$ \\
\hline & \multicolumn{3}{|c|}{$\begin{array}{l}{ }^{\mathrm{a}-\mathrm{d}} \chi^{2}=1.65 ; P=0.43 \\
{ }^{\mathrm{b}-\mathrm{c}} \chi^{2}=5.59 ; P=0.06 \\
{ }^{\mathrm{c}-\mathrm{d}} \chi^{2}=4.51 ; P=0.10\end{array}$} & \multicolumn{2}{|c|}{$\begin{array}{l}{ }^{\mathrm{a}-\mathrm{d}} \chi^{2}=1.66 ; P=0.20 \\
{ }^{\mathrm{b}-\mathrm{c}} \chi^{2}=0.005 ; P=0.94 \\
{ }^{\mathrm{c}-\mathrm{d}} \chi^{2}=0.94 ; P=0.33\end{array}$} \\
\hline
\end{tabular}

(B)

\begin{tabular}{|c|c|c|c|c|c|}
\hline & \multicolumn{3}{|c|}{$A H R$ genotypes } & \multicolumn{2}{|c|}{$A H R$ alleles } \\
\hline & $\operatorname{Arg} / \operatorname{Arg}(\%)$ & Arg/Lys (\%) & Lys/Lys (\%) & $\operatorname{Arg}(\%)$ & Lys (\%) \\
\hline Control $^{\mathrm{a}}$ & $30(27.8)$ & $60(55.6)$ & $18(16.6)$ & $120(55.6)$ & $96(44.4)$ \\
\hline Healthy volunteer ${ }^{\mathrm{b}}$ & $24(28.6)$ & $48(57.1)$ & $12(14.3)$ & $96(57.2)$ & $72(42.8)$ \\
\hline Nonendometriosis $^{\mathrm{c}}$ & $6(25.0)$ & $12(50.0)$ & $6(25.0)$ & $24(50.0)$ & $24(50.0)$ \\
\hline Endometriosis $^{\mathrm{d}}$ & $16(35.6)$ & $23(51.1)$ & $6(13.3)$ & $55(61.1)$ & $35(38.9)$ \\
\hline
\end{tabular}

Association between endometriosis and SNPs of $A H R$ and $A H R R$

We analyzed the frequencies of $A H R$ and $A H R R$ polymorphisms in women with and without endometriosis. The distribution of $A H R R$ genotypes conformed to HardyWeinberg equilibrium; distribution of the three genotypes of $A H R$ in healthy controls was similar to results reported by Kawajiri et al. (1995) (Table 3B). We also confirmed that there was no difference in the distribution of the three genotypes in both genes between healthy volunteers and women with a normal pelvis. No significant differences were observed in genotypic or allelic frequencies at $A H R$ and $A H R R$ loci between the control groups and patients with endometriosis (Table 3A,B). We also investigated for allelic frequencies of known polymorphisms in the $A R N T$ gene (D511N; Cao and Hegele, 2000) and the CYP1A1 promoter (G-469A and C-459T; Smart and Daly, 2000). However, we did not detect any of these polymorphisms in our subjects, indicating that they are rare in the Japanese population (data not shown).

\section{Discussion}

Recently, the level of $C Y P 1 A 1$ expression in patients with endometriosis has been reported to be higher than that in a nonendometriosis group (Bulun et al. 2000); the overexpression of CYP1A1 that can be observed in endometriosis suggests that a dioxin-activated signaling pathway may be relevant to promoting the pathological development and growth of endometrial tissue. However, constitutional genetic factors appear to contribute as well, because some cases of endometriosis are familial (Simpson et al. 1980; Lamb et al. 1986; Moen and Magnus 1993; Kennedy et al. 1995). Such circumstantial evidence suggests that the pathogenesis of endometriosis may involve predisposing genotypes of specific genes, especially genes that encode dioxin-related transcription factors, their regulators, and/or their targets.

Knowledge of the genetic organization of $A H R R$ is a prerequisite for a thorough screening of genotypes at polymorphic sites. Our data revealed that the $A H R R$ gene consists of ten exons encoding 698 amino acid residues. Furthermore, we found that, among Japanese individuals, AHRR protein consists of at least two different primary structures, and the difference reflects the replacement of one amino acid (Ala for Pro) at codon 185 in exon 5, which exists within the PAS domain (Fig. 1). Although our preliminary study has shown that this polymorphism does not affect susceptibility to endometriosis, it remains possible that Ala and Pro versions in the functional domain of AHRR protein may exert different activities with respect to dioxin and other arylhydrocarbons. The effect of this polymorphism on the functional and/or biochemical characteristics of AHRR, including dimerization activity, has yet to be studied, but it is clear that further investigation will be necessary to clarify the significance of the different forms of AHRR protein.

An amino acid-replacing polymorphism also exists in $A H R$, at codon 554 (Arg $\langle-\rangle$ Lys (G1721A) near the Glurich region in exon 10 (Kawajiri et al. 1995). Although association of this polymorphism with the CYP1A1inducing activity of $A H R$ has been reported in a Caucasian population (Smart and Daly 2000), our preliminary study showed no significant differences in genotypes of the same SNP of $A H R$ among Japanese women with and without 
endometriosis. Polymorphisms in the $A R N T$ gene and the $C Y P 1 A 1$ promoter are other candidates for modulating gene expression and/or function in the dioxin-activated signaling pathway. However, the known polymorphisms of $A R N T(\mathrm{D} 511 \mathrm{~N})$ and CYP1A1 promoter (G-469A and C$459 \mathrm{~T})$ were not detected in our subjects, even though all three polymorphisms have been reported in Caucasians (Cao and Hegele 2000; Smart and Daly 2000). Because other polymorphic sites may exist in these genes in the Japanese population, examination of a larger group of subjects will be necessary to clarify any possible associations with endometriosis.

Others have investigated possible associations between genetic polymorphism and predisposition to endometriosis in a few genes encoding compound metabolic enzymes such as GSTM1, arylamine N-acetyltransferase 2 (NAT2), and galactose-1-phosphate uridyl transferase (GALT) (Baranova et al. 1997; 1999; Cramer et al. 1996). The present study was limited to the examination of $A H R$ and $A H R R$ polymorphisms in a Japanese population sample. However, our relatively small sample may not have been sufficient for obtaining significant differences between controls and patients with endometriosis as regards $A H R$ and $A H R R$ genotypes. Therefore, a large-scale follow-up study will be required to determine whether evidence may, in fact, exist for the involvement of $A H R$ or $A H R R$ polymorphisms in susceptibility to endometriosis.

Acknowledgments We are grateful to Ms. Mieko Yanokura and Ms. Ai Watanabe for technical assistance.

\section{References}

Baranova H, Bothorishvilli R, Canis M, Albuisson E, Perriot S, Glowaczower E, Bruhat MA, Baranov V, Malet P (1997) Glutathione S-transferase M1 gene polymorphism and susceptibility to endometriosis in a French population. Mol Hum Reprod 3:775780

Baranova H, Canis M, Ivaschenko T, Albuisson E, Bothorishvilli R, Baranov V, Malet P, Bruhat MA (1999) Possible involvement of arylamine $\mathrm{N}$-acetyltransferase 2, glutathione S-transferases M1 and T1 genes in the development of endometriosis. Mol Hum Reprod 5:636-641

Bois FY, Eskenazi B (1994) Possible risk of endometriosis for Seveso, Italy, residents: an assessment of exposure to dioxin. Environ Health Perspect 102:476-477

Bulun SE, Zeitoun KM, Kilic G (2000) Expression of dioxin-related transactivating factors and target genes in human eutopic endometrial and endometriotic tissues. Am J Obstet Gynecol 182:767775

Cao H, Hegele RA (2000) Human aryl hydrocarbon receptor nuclear translocator gene $(A R N T)$ D/N511 polymorphism. J Hum Genet 45:92-93

Cramer DW, Hornstein MD, Ng WG, Barbieri RL (1996) Endometriosis associated with the N314D mutation of galactose-1-phosphate uridyl transferase (GALT). Mol Hum Reprod 2:149-152

Dolwick KM, Schmidt JV, Carver LA, Swanson HI, Bradfield CA (1993) Cloning and expression of a human Ah receptor cDNA. Mol Pharmacol 44:911-917

Ema M, Sogawa K, Watanabe N, Chujoh Y, Matsushita N, Gotoh O, Funae Y, Fujii-Kuriyama Y (1992) cDNA cloning and structure of mouse putative Ah receptor. Biochem Biophys Res Commun 184:246-253

Eskenazi B, Mocarelli P, Warner M, Samuels S, Vercellini P, Olive D, Needham L, Patterson D, Brambilla P (2000) Seveso Women's Health Study: a study of the effects of 2,3,7,8-tetrachlorodibenzo-pdioxin on reproductive health. Chemosphere 40:1247-1253

Fujisawa-Sehara A, Sogawa K, Yamane M, Fujii-Kuriyama Y (1987) Characterization of xenobiotic responsive elements upstream from the drug-metabolizing cytochrome $\mathrm{P}-450 \mathrm{c}$ gene: a similarity to glucocorticoid regulatory elements. Nucleic Acids Res 15:4179-4191

Futamura M, Nishimori H, Shiratsuchi T, Saji S, Nakamura Y, Tokino $\mathrm{T}$ (1999) Molecular cloning, mapping, and characterization of a novel human gene, MTA1-L1, showing homology to a metastasisassociated gene, MTA1. J Hum Genet 44:52-56

Hoffman EC, Reyes H, Chu FF, Sander F, Conley LH, Brooks BA, Hankinson O (1991) Cloning of a factor required for activity of the Ah (dioxin) receptor. Science 252:954-958

Ikegawa S, Isomura M, Koshizuka Y, Nakamura Y (1999) Cloning and characterization of human and mouse PROSC (proline synthetase co-transcribed) genes. J Hum Genet 44:337-342

Kawajiri K, Watanabe J, Eguchi H, Nakachi K, Kiyohara C, Hayashi S (1995) Polymorphisms of human Ah receptor gene are not involved in lung cancer. Pharmacogenetics 5:151-158

Kennedy S, Mardon H, Barlow D (1995) Familial endometriosis. J Assist Reprod Genet 12:32-34

Lamb K, Hoffmann RG, Nichols TR (1986 ) Family trait analysis: a case-control study of 43 women with endometriosis and their best friends. Am J Obstet Gynecol 154:596-601

Matsushita N, Sogawa K, Ema M, Yoshida A, Fujii-Kuriyama Y (1993) A factor binding to the xenobiotic responsive element (XRE) of P4501A1 gene consists of at least two helix-loop-helix proteins, Ah receptor and Arnt. J Biol Chem 268:21,002-21,006

Mayani A, Barel S, Soback S, Almagor M (1997) Dioxin concentrations in women with endometriosis. Hum Reprod 12:373-375

Mimura J, Ema M, Sogawa K, Fujii-Kuriyama Y (1999) Identification of a novel mechanism of regulation of Ah (dioxin) receptor function. Genes Dev 13:20-25

Moen MH, Magnus P (1993) The familial risk of endometriosis. Acta Obstet Gynecol Scand 72:560-564

Pimkhaokham A, Shimada Y, Fukuda Y, Kurihara N, Imoto I, Yang ZQ, Imamura M, Nakamura Y, Amagasa T, Inazawa J (2000) Nonrandom chromosomal imbalances in esophageal squamous cell carcinoma cell lines: possible involvement of the $A T F 3$ and $C E N P F$ genes in the 1q32 Amplicon. Jpn J Cancer Res 91:1126-1133

Poland A, Knutson JC (1982) 2,3,7,8-Tetrachlorodibenzo-p-dioxin and related halogenated aromatic hydrocarbons: examination of the mechanism of toxicity. Annu Rev Pharmacol Toxicol 22:517-554

Reyes H, Reisz-Porszasz S, Hankinson O (1992) Identification of the Ah receptor nuclear translocator protein (Arnt) as a component of the DNA binding form of the Ah receptor. Science 256:1193-1195

Rier SE, Martin DC, Bowman RE, Dmowski WP, Becker JL (1993) Endometriosis in rhesus monkeys (Macaca mulatta) following chronic exposure to 2,3,7,8-tetrachlorodibenzo-p-dioxin. Fundam Appl Toxicol 21:433-441

Simpson JL, Elias S, Malinak LR, Buttram VC Jr (1980) Heritable aspects of endometriosis. I. Genetic studies. Am J Obstet Gynecol 137:327-331

Smart J, Daly AK (2000) Variation in induced CYP1A1 levels: relationship to CYP1A1, Ah receptor and GSTM1 polymorphisms. Pharmacogenetics 10:11-24

Sugimoto N, Fukuda Y, Saito-Ohara F, Kamiyama R, Nakagawara A, Mukae N, Nagata S, Inazawa J (1999) The human caspase-activated DNase gene $(h C A D)$ : genomic structure, exonic single-nucleotide polymorphisms, and a highly polymorphic dinucleotide repeat at the hCAD locus. J Hum Genet 44: 408-411

Telakowski-Hopkins CA, King RG, Pickett CB (1988) Glutathione Stransferase Ya subunit gene: identification of regulatory elements required for basal level and inducible expression. Proc Natl Acad Sci USA 85:1000-1004

Whitelaw M, Pongratz I, Wilhelmsson A, Gustafsson JA, Poellinger L (1993) Ligand-dependent recruitment of the Arnt coregulator determines DNA recognition by the dioxin receptor. Mol Cell Biol $13: 2504-2514$ 